\section{Relative Virulence of Agrobacterium Strains on Strawberry}

Sandra L. Uratsu, Hamid Ahmadi, Royce S. Bringhurst, and Abhaya M. Dandekar

Department, of Pomology, University of California, Davis, CA 95616

Additional index words. Fragaria vesca, Agrobacterium rhizogenes, A. tumefaciens, opines, tumor formation

Abstract. Several strains of Agrobacterium tumefaciens and A. rhizogenes were shown to form tumors on runners of the diploid strawberry species Fragaria vesca L. Tumors, weighing from 0.1 to $8.3 \mathrm{mg}$, appeared from 2 to 4.5 weeks after infection. The majority of tumors tested for opine synthesis by high-voltage paper electrophoresis analysis showed positive results. These results demonstrate that diploid strawberry plants are susceptible to infection with Agrobacterium and that there are differences in the relative virulence of Agrobacterium strains.

Agrobacterium is a genus of bacteria that resides in the soil and causes the common disease crown gall on a variety of dicotyledonous plants. Recently, this organism has gained widespread importance as a vector to transfer genes into plants. Currently, the infection of strawberry by Agrobacterium is not a problem in strawberry nurseries or production fields; therefore, it is not clear whether this plant can be transformed by Agrobacterium. The natural host range of A. tumefaciens and A. rhizogenes can be determined by demonstrating the ability of these bacteria to form crown gall or hairy root disease (De Cleene and De Ley, 1976, 1981).

Pathogenicity of Agrobacterium depends on the presence of a Ti or Ri plasmid. During infection, this pathogen transfers a portion of its Ti or Ri plasmid, the T-DNA segment, to the plant's genome (Chilton et al.,. 1977, 1982). Transcription and translation of genes present in the T-DNA causes crown gall tumors in A. tumefaciens or hairy root disease in A. rhizogenes (Chilton et al., 1977, 1982). Thus, the appearance of tumors or abnormally prolific roots, respectively, is a good indication that transformation has occurred. The T-DNA also contains genes that encode the synthesis of opines. The presence of these compounds in plant tissue extracts is unique to tissue infected with Agrobacterium. Dif-

Received for publication 6 Nov. 1989. We are grateful to the following for providing us with Agrobacterium strains: M.D. Chilton (A208); C.I. Kado (C58, Ach5); E.W. Nester (A722, A281, A4, R1000); V. Knauf (K12, K12×167, K12×563E, A4T×178); J. Tempé (15955); S. Rogers (pMON200); and G. Strobel (232). The cost of publishing this paper was defrayed in part by the payment of page charges. Under postal regulations, this paper therefore must be hereby marked advertisement solely to indicate this fact.

${ }^{1}$ To whom reprint requests should be addressed. ferent strains of Agrobacterium induce the synthesis of different opines; included among these are nopaline (NOP) and octopine (OCT) (Bomhoff et al., 1976), mannopine (MOP), mannopinic acid (MOA), agropine (AGR), and agropinic acid (AGA) (Petit et al., 1983).

We have used diploid strawberry $F$. vesca in these studies to determine its susceptibility inoculated with 523 medium. to infection by Agrobacterium. It is the most extensively distributed species of this genus and can be found in the northern regions of America, Asia, and Europe. The cultivated strawberry is an octaploid and, therefore, genetically more complex than the diploid varieties.

Plant material. The plant source used in this investigation was a runner-producing derivative of the $F$. vesca, alpine clone ( $2 \mathrm{n}$ $=14, x=7)$. Plants were grown in a growth chamber at $24 \mathrm{C}$ under a light intensity of 50 $\mu \mathrm{mol} \cdot \mathrm{s}^{-1} \cdot \mathrm{m}^{-2}$. Runners used for infection were 4 to 6 weeks old.

Bacterial strains. Various tumor and rootinducing strains of Agrobacterium were used to infect the strawberry runners. Some characteristics of the Agrobacterium strains used in our experiments are shown in Table 1.

Culture medium and growth of bacteria. The Agrobacterium cultures were grown at 26 to $28 \mathrm{C}$ in 523 medium (Kado et al., 1972). Kanamycin $\left(100 \mu \mathrm{g} \cdot \mathrm{ml}^{-1}\right)$ and spectinomy$\operatorname{cin}\left(50 \mu \mathrm{g} \cdot \mathrm{m}^{-1}\right)$ were supplemented in the growth medium as required for bacteria that contained the corresponding resistance gene.

Tumor induction. Runners were wounded by cutting through the epidermal tissue with

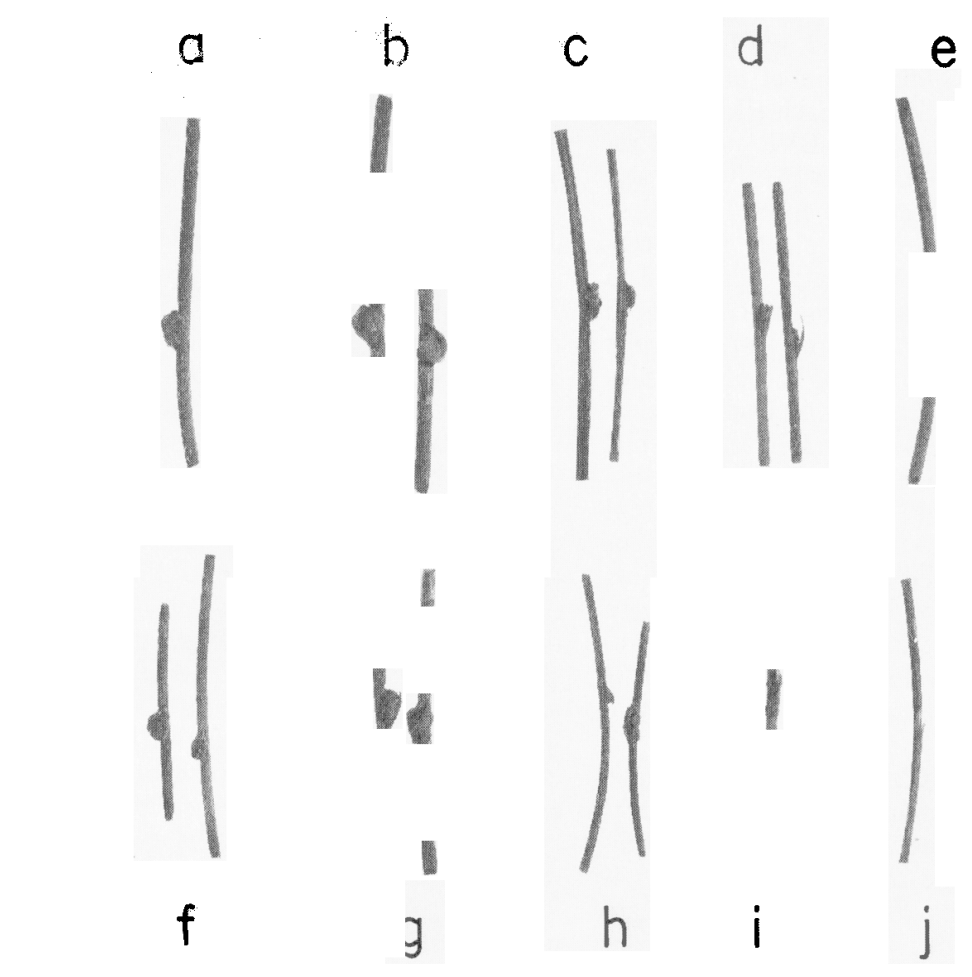

Fig. 1. Tumor formation on runners 4 weeks after inoculation with Agrobacterium strains. Note tumor size varies even within a given strain of Agrobacterium. Lanes a-h show runners inoculated with $A$. tumefaciens strains A208, C58, A722, A281, K12×562E, K12×167, B6S3×200, and 15955, respectively. Lane i shows runners inoculated with A. rhizogenes strain R1000. Lane j shows runners 


\begin{tabular}{|c|c|c|c|c|c|c|c|c|}
\hline \multirow[b]{2}{*}{ Strain } & \multirow{2}{*}{$\begin{array}{c}\mathrm{Ti} \\
\text { plasmid }\end{array}$} & \multicolumn{6}{|c|}{ Opine ${ }^{x}$} & \multirow[b]{2}{*}{ References } \\
\hline & & OCT & NOP & AGR & $\mathrm{AGA}$ & MOP & MOA & \\
\hline \multicolumn{9}{|l|}{ A. tumefaciens } \\
\hline A208 & pTiT37 & - & + & - & - & - & - & Sciaky et al., 1978 \\
\hline C58 & pTiC58 & - & + & - & $\rightarrow$ & - & - & Sciaky et al,, 1978 \\
\hline A 722 & pTiA6 & + & - & + & + & + & + & Garfinkel and Nester, 1980 \\
\hline $\mathrm{K} 12$ & pTiA6 & + & - & + & + & + & + & Dandekar et al., 1987 \\
\hline $\mathrm{K} 12 \times 562 \mathrm{E}$ & pTiA6:562E & + & - & + & + & + & + & Dandekar et al., 1987 \\
\hline $\mathrm{K} 12 \times 167$ & pTiA6:167 & + & - & + & + & + & + & Dandekar et al., 1987 \\
\hline A281 & pTiBO542 & - & - & + & + & + & + & Petit et al., 1983 \\
\hline $\mathrm{B} 6 \mathrm{~S} 3 \times 200$ & pMON200II & + & + & + & + & + & + & Fraley et al., 1985 \\
\hline Ach 5 & pTiAch5 & + & - & + & + & + & + & Petit et al., 1983 \\
\hline 15955 & pTi15955 & + & - & + & + & + & + & Petit et al., 1983 \\
\hline \multicolumn{9}{|l|}{ A. rhizogenes } \\
\hline $\mathrm{A} 4 \mathrm{~T} \times 178$ & pRiA4T & - & - & + & + & + & + & R.C. Gardner, personal communication \\
\hline A4 & $\mathrm{pHr}(\mathrm{A} 4)$ & - & - & + & + & + & + & Moore et al., 1979 \\
\hline R1000 & $\mathrm{pRiA} 4 \mathrm{~b}$ & - & - & + & + & + & + & White et al., 1985 \\
\hline 232 & $\mathrm{ND}^{\mathrm{y}}$ & ND & ND & ND & ND & ND & ND & Strobel and Nachmias, 1985 \\
\hline
\end{tabular}

${ }^{2}$ Oct $=$ octopine, $\mathrm{NOP}=$ nopaline, $\mathrm{AGR}=$ agropine, $\mathrm{AGA}=$ agropinic acid, $\mathrm{MOP}=$ mannopine, $\mathrm{MOA}=$ mannopinic acid ${ }^{y} \mathrm{ND}=$ not determined.

Table 2. Analysis of tumor formation in strawberry.

\begin{tabular}{|c|c|c|}
\hline Strain & $\begin{array}{c}\text { Tumor } \\
\text { formation }^{z}\end{array}$ & $\begin{array}{l}\text { Tumor wty } \\
\text { (mg) }\end{array}$ \\
\hline \multicolumn{3}{|l|}{ A. tumefaciens } \\
\hline A208 & $4 / 10$ & $0.6-2.9(1.9)$ \\
\hline $\mathrm{C} 58$ & $2 / 10$ & $4.6-5.3(4.9)$ \\
\hline $\mathrm{A} 722$ & $6 / 10$ & $0.7-2.2(1.3)$ \\
\hline $\mathrm{K} 12$ & $3 / 10$ & $0.6 \quad(0.6)$ \\
\hline $\mathrm{K} 12 \times 562 \mathrm{E}$ & $7 / 10$ & $0.4-2.9(1.4)$ \\
\hline $\mathrm{K} 12 \times 167$ & $6 / 10$ & $0.1-1.6(0.8)$ \\
\hline A281 & $5 / 10$ & $0.4-0.9(0.7)$ \\
\hline B $6 \mathrm{~S} 3 \times 200$ & $8 / 10$ & $0.2-3.3(1.4)$ \\
\hline Ach 5 & $1 / 3$ & $8.3 \quad(8.3)$ \\
\hline 15955 & $8 / 10$ & $0.2-4.7(1.6)$ \\
\hline \multicolumn{3}{|l|}{ A. rhizogenes } \\
\hline $\mathrm{A} 4 \mathrm{~T} \times 178$ & $6 / 10$ & $0.6-1.5(1.1)$ \\
\hline A4 & $4 / 10$ & $0.1-2.2(1.0)$ \\
\hline R1000 & $8 / 17$ & $0.2-2.0(0.9)$ \\
\hline 232 & $6 / 10$ & $0.2-0.6(0.4)$ \\
\hline Control & $0 / 10$ & -.- \\
\hline
\end{tabular}

${ }^{2}$ Number of tumors/number of infections.

${ }^{y}$ Range of tumor weights (average weight).

a sterile scalpel. One drop $(2-5 \mu \mathrm{l})$ of a culture of Agrobacterium grown for $16 \mathrm{~h}$ and having a cell density of $5 \times 10^{8}$ cells $/ \mathrm{ml}$ (as measured by absorbance at $420 \mathrm{~nm}$ ) was placed on each wound. The wounded surfaces were then wrapped with parafilm to prevent drying. Tumors were harvested 4 to 8 weeks after inoculation. Kalanchoe daigremontiana plants were used as positive controls to check for oncogenicity of the various strains. The Kalanchoe plants were wounded by making incisions on the leaf surface and then were inoculated with the various Agrobacterium strains.

Opine analysis. Extracts for opine analysis were prepared by placing 1 to $4 \mathrm{mg}$ of tumor tissue in an Eppendorf tube containing 200. $\mu \mathrm{l}$ of distilled water and boiling it for $10 \mathrm{~min}$. The tumor tissue was removed by centrifugation $(5000 \times g, 10$ rein). The extract was then dried in a speed vac (Savant, New York) and resuspended in water to 0.5 $\mu \mathrm{l} \cdot \mathrm{mg}^{-1}$ of tissue. One to $2 \mu \mathrm{l}$ of extract was spotted onto Whatman 3-mm paper along with $1 \mu \mathrm{l}$ of standards of the NOP/OCT family (1 mg octopine, nopaline, and arginine/ $\mathrm{ml})$ or $1 \mu \mathrm{l}$ of standards belonging to the mannityl opine family (1 mg MOP, MOA, AGP, and AGA $/ \mathrm{ml}$; authentic standards of these opines were provided by J. Tempé). Aqueous methyl green solution, which migrates just behind arginine, was used as a visual marker during electrophoresis. The paper was moistened with the appropriate electrophoresis buffer immediately before the current was applied. For analysis of the NOP/ OCT family, the buffer used was $5 \%$ formic acid and $15 \%$ glacial acetic acid; for the mannityl opines, the buffer was 3\% formic acid and $6 \%$ glacial acetic acid, Paper electrophoresis was performed at 10 volts $\cdot \mathrm{cm}$ for $40 \mathrm{~min}$. The paper was then dried. Nopaline and octopine, which react with the fluorescent compound 9,10-phenanthrenequinone, were assayed as described by Otten and Schilperoort (1978). The detection of agropine, agropinic acid, mannopine, and mannopinic acid (silver nitrate-positive compounds) was performed as described by Petit et al. (1983).

Tumors appeared from 2 to 4.5 weeks after inoculation of strawberry runners with Agrobacterium (Fig. 1). Of 14 Agrobacterium strains $(10 \mathrm{~A}$. tumefaciens and four $A$. rhi- zogenes) used to infect strawberry runners, all 14 produced tumors of various sizes (Table 2). Strains containing pTi15955 (15955) and pMON 200 II $($ B6S3 3200$)$ were found to be the most infectious (Table 2), producing tumors in eight of the 10 sites inoculated: The average weight of the tumors incited by these strains was under $2 \mathrm{mg}$. Strains that contained pTiA6 (A722) or its recombinant derivatives $\mathrm{K} 12 \times 562 \mathrm{E}$ and $\mathrm{K} 12 \times 167$ produced tumors in more than $60 \%$ of infected sites (Table 2); their average weights were also under $2 \mathrm{mg}$. The highly virulent strain A281 (Hood et al., 1986a, 1986b) produced average-sized tumors in five of 10 sites inoculated. Strains containing the Ti plasmids pTiAch5 and pTiC58 produced the largest tumors but were found to be the least infectious (one of three sites and two of 10 sites, Table 2). The tumor morphology in all cases was hard and compact with no visible differentiated structures (buds, leaves, or roots).

No root formation was observed when $A$. rhizogenes was used to infect strawberry; tumors were found, however, at the infection sites. The A. rhizogenes strains 232 and A4T $\times 178$ were the most infectious of the Rhizogenes strains tested (Table 2), and they produced tumors on six of 10 infected sites. All tumors weighed under $2 \mathrm{mg}$. Control runners inoculated with sterile medium failed to produce any tumors.

Opine expression in tumors was verified by analysis of tumors for the presence of opine compounds. The aim of the analysis was to determine the presence of the nopaline/octopine family and/or the mannityl opine family (AGR, AGA, MOP, MOA). Sixtythree tumors were analyzed for opines, 53 of which were analyzed for all six opines. Ten tumors that were too small to be analyzed for both opine families were analyzed only for the presence of the mannityl opine family. The analysis for the presence of both families of opine compounds was necessary because many of the strains were capable of synthesizing more than one class of opine (Table 1). Both agropine and mannopine could be clearly distinguished in our analysis (Fig. 2 ), but mannopinic acid comigrated with mannopine, and agropinic acid comigrated 
Table 3. Characterization of opines present in strawberry tumors.

\begin{tabular}{lcccc}
\hline \hline \multirow{2}{*}{ Strain } & \multicolumn{3}{c}{ Opines $^{z}$} \\
\cline { 2 - 5 } & AGR & MOP/MOA & NOP & OCT \\
\hline A208 & $0 / 4$ & $0 / 4$ & $3 / 3$ & $0 / 3$ \\
C58 & $0 / 2$ & $0 / 2$ & $2 / 2$ & $0 / 2$ \\
A722 & $0 / 4$ & $4 / 4$ & $0 / 4$ & $0 / 4$ \\
K12 & $1 / 1$ & $1 / 1$ & ND & ND \\
K12 5562 E & $7 / 7$ & $7 / 7$ & $0 / 6$ & $4 / 6$ \\
K12 167 & $6 / 6$ & $6 / 6$ & $0 / 4$ & $4 / 4$ \\
A281 & $5 / 5$ & $5 / 5$ & ND & ND \\
B6S3 200 & $8 / 8$ & $8 / 8$ & $7 / 7$ & $0 / 7$ \\
Ach5 & $1 / 1$ & $1 / 1$ & $0 / 1$ & $1 / 1$ \\
15955 & $4 / 4$ & $4 / 4$ & $0 / 3$ & $3 / 3$ \\
A4T 5178 & $2 / 6$ & $2 / 6$ & $0 / 4$ & $0 / 4$ \\
A4 & $2 / 3$ & $2 / 3$ & ND & ND \\
R1000 & $0 / 8$ & $0 / 8$ & $0 / 7$ & $0 / 7$ \\
232 & $0 / 4$ & $0 / 4$ & $0 / 2$ & $0 / 2$ \\
\hline
\end{tabular}

${ }^{2}$ Number of positive/number tested.

${ }^{y}$ Not determined.

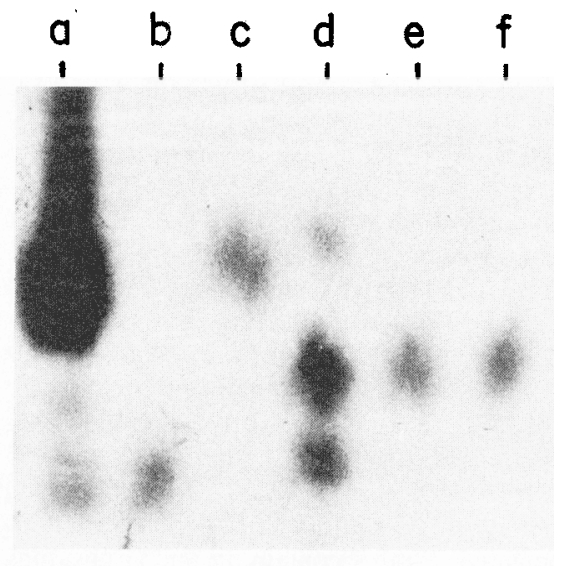

Pig. 2. Electrophoretic analysis of the opines AGR (lane b), AGA (lane c), MOA (lane e), and MOP (lane f) standards as compared to a tumor extract from $\mathrm{B} 6 \mathrm{~S} 3 \times 200$ (lane a). Lane d contains a mixed standard of AGR, AGA, MOA, and MOP.

with neutral sugars that form the bulk of silver nitrate-positive cellular components. Therefore, we have scored for either AGR or MOP/MOA m our results (Table 3). All tumors formed after infection by strains containing pTiA6 (A722, K12) or its derivatives $(\mathrm{K} 12 \times 562 \mathrm{E}, \mathrm{K} 12 \times 167)$ produced the mannityl opines; $50 \%$ to $60 \%$ of these tumors also produced octopine (Table 3). Similar results were found for the other octopineproducing strains Ach5 and 15955. All tumors from $\mathrm{B} 6 \mathrm{~S} 3 \times 200$ contained nopaline and the mannityl opines but not octopine.

Two sets of tumors formed by A. rhizogenes R1000 and 232 failed to show any signs of opine synthesis, either in the OCT/ NOP assay or the MOP/MOA/AGR assay. Control runners not inoculated or inoculated with sterile medium did not produce any opine compounds.

Fourteen tumor- and root-forming strains of Agrobacterium were used to determine the efficiency of infection of diploid strawberry $F$. vesca. Interestingly, infection of strawberry with $A$. rhizogenes resulted in the formation of tumors at the infection sites rather than the formation of roots. This observation is consistent with those made by De Cleene and De Ley (1981). No organized microstructure were seen by microscopic examination of tumors formed by A. rhizogenes or A. tumefaciens.

A majority of the octopine-producing tumors also were found to contain mannityl opines, suggesting the transfer of both $\mathrm{T}_{\mathrm{L}}$ and $\mathrm{T}_{\mathrm{R}}$-DNA. In the case of octopine-producing Agrobacterium, it is known that the T-DNA is not contiguous but is comprised of two separate T-DNA structures, $\mathrm{T}_{\mathrm{L}}$ and $\mathrm{T}_{\mathrm{R}}$ (Thomashow et al., 1980). $\mathrm{T}_{\mathrm{L}}$-DNA contains genes for the synthesis of octopine (Barker et al., 1983; Garfinkel et al., 1981; Leemans et al., 1982), whereas $T_{R}$-DNA contains genes that encode synthesis of the mannityl group of opines (Barker et al., 1983; Salomon et al., 1984).

Fragaria vesca alpine clones are known for aroma and good flavor, but are not commercially significant because they are highly susceptible to viral infections (used as a viral indicator plant). The genome size is small, $\approx 22$ times that of $E$. coli (Ahmadi et al., 1988). They are highly inbred (isogenic), with the availability of many isolated single-gene mutants. Therefore alpine clones are suitable for molecular studies and could be developed as an experimental system for perennial woody plants. They have a generation time of only 7 weeks (seed to seed), a rapid asexual mode of propagation, and can be readily regenerated from various vegetative tissues (P.L. Schuerman and A. M.D., unpublished data). Fragarai vesca can hybridize with octoploid species with ease (Ahmadi et al., 1990; Scott, 1951). Their pentaploid hybrids usually produce decaploid offspring (unreduced gamete) or may be doubled synthetically to obtain fertile decaploid derivatives. The identification of suitable strains, shown here, is the first step in the development of a functional Agrobacterium-mediated gene transfer system. Useful traits, such as herbicide, pest, and disease resistance, once introduced via transformation in $F$. vesca, could be introgressed into octoploid species, resulting in new cultivars with desirable genes.

\section{Literature Cited}

Ahmadi, H., R.S. Bringhurst, S.C. Uratsu, and A.M. Dandekar. 1988. 'Alpine' Fragaria vesca, a woody plant model for molecular study. Genome 30(Suppl. 1):35.31.22.

Ahmadi, H., R.S. Bringhurst, and V. Voth. 1990. Modes of inheritance of photoperiodism in Fragaria. J. Amer. Soc. Hort. Sci. 115:146-152. Barker, R.F., K.B. Idler, D.V. Thompson, and J.D. Kemp. 1983. Nucleotide sequence of the T-DNA region from the Agrobacterium tumefaciens octopine $\mathrm{Ti}$ plasmid pTi15955. Plant Molec. Biol. 2:335-350.

Bomhoff, G., P.M. Klapwijk, H.C.M. Kester, R.A. Schilperoort, J.P. Hemalsteens, and J. Schell. 1976. Octopine and nopaline synthesis and breakdown genetically controlled by a plasmid of Agrobacterium tumefaciens. Molec. Gen. Genet. 145:177-181.

Chilton, M.D., M.H. Drummond, D.J. Merle, D. Sciaky, A.L. Montoya, M.P. Gordon, and E.W. Nester. 1977. Stable incorporation of plasmid DNA into higher plant cells: The molecular basis of crown gall tumorigenesis. Cell 11:263271.

Chilton, M.D., D.A. Tepfer, A. Petit, C. David, F. Casse-Delbart, and J. Tempé. 1982. Agrobacterium rhizogenes inserts T-DNA into the genomes of the host plant root cells. Nature (London) 295:432-434.

Dandekar, A.M., P.K. Gupta, D.J. Durzan, and V. Knauf. 1987. Transformation and foreign gene expression in micropropagated douglas-fir (Pseudotsuga menziesii). Biotechnology 5:587590.

De Cleene, M. and J. De Ley. 1976. The host range of crown gall. Bet. Rev. 42:389-466.

De Cleene, M. and J. De Ley. 1981. The host range of infectious hairy-root. Bet. Rev. 41147 194.

Fraley, R.T., S.G. Rogers, R.B. Horsch, D.A Eichholtz, J.S. Flick, C.L. Fink, N.L. Hoffman, and P.R. Sanders. 1985. The SEV system: A new disarmed Ti plasmid vector system for plant transformation. Biotechnology 3:629635 .

Garfinkel, D.J. and E.W. Nester. 1980. Agrobacterium tumefaciens mutants affected in crown gall tumorigenesis and octopine catabolism. J. Bacteriology 144:732-743.

Garfinkel, D.J., R.B. Simpson, L.W. Ream, F.F. White, M.P. Gordon, and E.W. Nester. 1981. Genetic analysis of crown gall: Fine structure map of the T-DNA by site-directed mutagenesis. Cell 27:143-153.

Hood, E.E., W.S. Chilton, M.D. Chilton, and R.T., Fraley. 1986a. T-DNA and opine synthetic loci in tumors incited by Agrobacterium tumefaciens A281 on soybean and alfalfa plants. J. Bacteriology 168:1283-1290.

Hood, E.E., G.L. Helmer, R.T. Fraley, and M,D. Chilton. 1986b. The hypervirulence of Agrobacterium tumefaciens A281 is encoded in a region of pTiBo542 outside of T-DNA. J. Bacteriology 168:1291-1301.

Kado, C.I., M.G, Heskett, and R.A. Langley. 1972. Studies on Agrobacterium tumefaciens: Characterization of strains 1D135 and B6, and analysis of the bacterial chromosome, transfer RNA and ribosomes for tumor-inducing ability. Physiol. Plant Pathol. 2:47-57.

Leemans, J., R. Deblaere, L. Willmitzer, H. DeGreve, J.P. Hernalsteens, M. Van Montagu, and J. Schell 1982. Genetic identification of functions of $\mathrm{T}_{\mathrm{L}}$-DNA transcripts in octopine crown galls. EMBO J. 1:147-152.

Moore, L., G. Warren, and G. Strobel. 1979. Involvement of a plasmid in the hairy root disease of plants caused by Agrobacterium rhizogenes. Plasmid 2:617-626.

Otten, L.A.B.M. and R.A. Schilperoort. 1978. A rapid micro scale method for the detection of lysopine and nopaline dehydrogenase activities. 
Biochem. Biophys. Acta 527:497-500.

Petit, A., C. David, G.A. Dahl, J.G. Ellis, P. Guyon, F. Casse-Delbart, and J. Tempe. 1983. Further extension of the opine concept: Plasmids in Agrobacterium rhizogenes cooperate for opine degradation. Molec. Gen. Genet. 190:204214.

Salomon, F., R. Deblaere, J. Leemans, J.P. Hernalsteens, M. Van Montagu, and J. Schell. 1984. Genetic identification of functions of TR-DNA transcripts in octopine crown galls. EMBO J. 3:141-146.

Sciaky, D., A.L. Montoya, and M.D. Chilton. 1978. Fingerprints of Agrobacterium Ti plasmids. Plasmid 1:238-253.

Scott, D.H. 1951. Cytological studies on polyploids derived from tetraploid Fragaria vesca and cultivated strawberries. Genetics 36:311331

Strobel, G.A. and A. Nachmias. 1985. Agrobacterium rhizogenes promotes the initial growth of bare root stock almond. J. Gen. Microbiol. 131:1245-1249.

Thomashow, M.F., R. Nutter, A.L. Montoya, M.P. Gordon, and E.W. Nester. 1980. Integration and organization of $\mathrm{Ti}$ plasmid sequences in crown gall tumors. Cell 19:729-739.

White, F.F., B.H. Taylor, G.A. Huffman, M.P. Gordon, and E.W. Nester. 1985. Molecular and genetic analysis of the transferred DNA regions of the root-inducing plasmid of Agrobacterium rhizogenes. J. Bacteriology 164:33-44. 